\title{
Kosovo - en tvivlsom proces
}

\section{Thomas Hjortsø}

\section{Forhandlinger om en ny stat i Europa er nu gået i gang, efter at det internationale samfund er besluttet på at få afklaret Kosovos fremtidige status. Så besluttet, at FN-rapporten, der banede vej for forhandlinger, ligner bestillingsarbejde}

Allerede da den erfarne danske Balkan-diplomat Søren Jessen-Petersen kom til Kosovo som FN's chef, kunne man mærke, hvor det bar hen. På et af sine første pressemøder sagde han: "Der er grænser for, hvor længe man kan holde et sted i uvished."

Det var i august 2004 - nogle måneder efter, at yderligtgående albanere var gået til angreb på medlemmer af det serbiske mindretal med det resultat, at 19 blev dræbt og 4.000 fordrevet. Uroen i marts 2004 var den værste i Kosovo, siden krigen sluttede i 1999. Volden kom sandsynligvis som en reaktion på, at der ikke var udsigt til at få afklaret Kosovos fremtid, men også de manglende jobmuligheder spillede ind.

I Kosovos hovedby Pristina tænkte mange internationale medarbejdere, at reaktionen måtte blive, at en- ten forstærker det internationale samfund sin indsats, eller også gør man det modsatte, nemlig trækker sig ud. Nu bagefter står det klart, at man valgte begge dele. Først sendte man flere soldater til NATO-styrken i Kosovo, KFOR.

Og bagefter begyndte man som den nyudnæwnte Kosovo-chef, Søren Jessen-Petersen at tale om en løsning - at få afklaret Kosovos status i håb $\mathrm{om}$, at det vil skabe stabilitet $\mathrm{og}$ mindske risikoen for vold, og med den bagtanke, at det internationale samfund kan reducere sin indsats i Kosovo. Der er også brug for de 18.000 soldater i KFOR-styrken andre steder - for eksempel i Irak eller Afghanistan.

KFOR havde været i landet, fra NATO rykkede ind i Kosovo i juli 1999, og lige siden havde man lagt problemet Kosovo ned i en skuffe. Dér blev problemet bedst opbevaret, 
mente man, for på den ene side kunne man ikke ignorere, at 90 procent af de to millioner indbyggere $\mathrm{i}$ Kosovo - nemlig albanerne - vil have selvstændighed. Og især efter serbiske styrkers overgreb mod den albanske befolkning i 1998-99 var det udelukket at lade Kosovo vende tilbage til Serbien. Formelt var Kosovo ellers ifølge FN's resolution 1244 fra 1999 en del af Jugoslavien, der senere blev omdøbt til Serbien \& Montenegro. Men reelt blev Kosovo styret af FN.

På den anden side var det også svært for de vigtigste aktører, Den Europæiske Union og USA, at svigte de demokratiske kræfter i Serbien ved at tage Kosovo fra Serbien - især efter at reformtilhængere styrtede Slobodan Milosevic i år 2000. Langt ind i moderate serberes rækker er der stærke følelser knyttet til Kosovo, selv om mange realistiske serbere godt ved, at Kosovo er tabt. EU og USA kunne heller ikke se bort fra frygten for, at yderligtgående nationalister vil vinde frem i Serbien, hvis Kosovo blev tabt.

\section{En stat ad bagdøren}

Der er stadig folkeretlig tvivl om, hvorvidt Kosovo har ret til selv at bestemme sin skæbne på samme måde som de jugoslaviske republikker. Kosovo var nemlig ikke en republik i Jugoslavien som for eksempel Kroatien og Serbien. Kosovo havde ifølge Jugoslaviens grundlov fra 1974 sta- tus som en selvstyrende enhed under Serbien på samme måde som Vojvodina i det nordlige Serbien.

Kosovo kom i nyere tid først ind under Serbien i forbindelse med Balkan-krigene i 1912-13, så det er langt fra givet, at Serbien har en historisk ret til området. Kosovo var dog en del af et tidligt serbisk rige $\mathrm{i}$ 12-1300 tallet, hvilket flere klostre fra den tid stadig fortæller om. Det mytologiske slag på Kosovo Polje i 1389 er også en del af den serbiske fortid. Under den osmanniske kontrol derefter og helt op til 1912 boede der både albanere og serbere $\mathrm{i}$ området foruden andre mindretal.

Kosovo har aldrig været et selvstændigt land - nogle vil sige, at det aldrig har haft et selvstændigt præg $\mathrm{i}$ den forstand, at det altid har været en del af et land. Men under FN's ledelse siden 1999 har Kosovo fået karakter af en stat med egne pas og lufthavn og andre internationale symboler - ofte i strid med de serbiske myndigheder, som naturligt nok har modarbejdet den proces, fordi man i Beograd så den som et forsøg på at skaffe et selvstændigt Kosovo ad bagdøren.

På det mere åbne og politiske plan er der foregået en proces, som blev indledt med en række standarder, som Kosovo skulle leve op til inden for menneskerettigheder, demokrati og økonomi. Standarderne, der blev opfundet i 2002 af FN's styre i Kosovo, fungerede ifølge onde tunger i begyndelsen som et påskud 
til at undgå et uafhængigt Kosovo. Det internationale samfund var ikke interesseret $i$ at støde Serbien fra sig, og man var sikker på, at Kosovo aldrig kunne leve op til standarderne. Sloganet hed "standarder før status".

Siden skiftede det internationale samfund holdning efter uroen $\mathrm{i}$ marts 2004. Man fandt ud af, at man kunne bøje standarderne, så de nu kunne bruges til det modsatte formål - altså selvstændighed. Der er mange - også kritiske albanere i Kosovo - som mener, at standarderne er blevet bøjet så kraftigt, at de passer til formålet.

FN-chefen Søren Jessen-Petersen og andre FN-chefer før ham har løbende vurderet, om Kosovo har levet op til standarderne. Søren Jessen-Petersens første rapporter til FN-hovedkvarteret i New York var ikke præget af jubel over situationen.

Det så især dårligt ud med det serbiske mindretals bevægelsesfrihed. Serberne skulle ofte have eskorte af KFOR-soldater for at bevæge sig uden for deres enklaver. Et andet problem var, at de serbiske fordrevne ikke havde den store lyst til at vende hjem til Kosovo på trods af ihærdig international indsats og økonomisk hjælp. Kun nogle få tusinde ud af måske 150.000 fordrevne serbere var i løbet af seks år vendt hjem.

Men gradvist blev situationen lidt bedre, og det blev noteret i Søren
Jessen-Petersens rapporter. I maj i år besluttede $\mathrm{FN}$ at bede den norske NATO-ambassadør og Balkan-kender Kai Eide om at vurdere, om Kosovo lever op til standarderne, og om der er basis for at indlede forhandlinger om at fastlægge en status for Kosovo.

\section{Leverer konklusionerne}

Når man bad Kai Eide om det, var det netop for at få en udefra, så man ikke havde FN i Kosovo til at vurdere sine egne bestræbelser. Men når man valgte Kai Eide, så var det også, fordi man ville være sikker på, at man fik den rigtige konklusion, nemlig, at der kan indledes forhandlinger.

Han var året før blevet bedt af FN om at udarbejde en tilsvarende rapport. Det var efter uroen i marts 2004. I rapportens konklusion fra august samme år noterer han, at forhandlinger om en endelig status for Kosovo "ikke kan udskydes meget længere." Og at der ikke vil komme "et ideelt tidspunkt til at begynde den slags forberedelser - ikke engang et godt tidspunkt."

I september 2004 uddybede Kai Eide så på en konference, at man med hensyn til Kosovo "skulle standse en politik med at fastholde en ubekvem status quo og tage skridt til at løse de tilbageværende problemer." Og han sagde også, at "der ikke er noget godt tidspunkt at løse Kosovos endelige status på, men at 
det må gøres og jo hurtigere jo bedre."

Hvis Kai Eide havde kunnet klemme sig ned i miljøminister Connie Hedegaards sko, så havde han da været langt mere inhabil end miljøministeren, da hun kommenterede Bilka-sagen i Horsens, før den var afgjort. Det førte da også den tidligere amerikanske ambassadør i Serbien, William Montgomery, til at sige i maj i år: "Jeg kunne allerede nu skrive rapporten, og dens hovedkonklusion vil lyde sådan her: Der er stadig visse alvorlige problemer, som Kosovos myndigheder helt klart må gøre noget ved med hjælp og overvågning fra det internationale samfund, men der er på den anden side sket så store fremskridt, at de tillader, at diskussionen om Kosovos status kan begynde."

Er der noget som tidligere diplomater? Den nuværende diplomat Kai Eide derimod blev fornærmet over den tidligere amerikanske ambassadørs løssluppenhed, og nordmanden mente ikke, at Montgomerys udtalelser ville komme til at passe. Kai Eide lovede en fuldstændig fair og nøgtern gennemgang.

I den forbindelse er det måske værd at minde om, hvad nogle internationale embedsmænd i Kosovo siger anonymt: "De rapporter, vi skriver om situationen her, kan se ret dystre ud, men når de har været en tur omkring ledelsen, ser de pludselig meget pænere ud." Ledelsen er FN's ledelse i Kosovo.

\section{Mange ord for dyster}

Kai Eide kom så med sin nye rapport i oktober i år, og den indeholdt mange synonymer for dyster. Blandt andet om mulighederne for at skabe et multi-etnisk samfund og om den $\varnothing$ konomiske situation. Når det gjaldt om at leve op til standarderne, var der sket en "ujævn" implementering, som han kaldte det.

Han er særlig kritisk over for politi og retsvæsen. Han skriver, at "retssikkerheden er hæmmet af en mangel på evne og parathed til at håndhæve loven på alle niveauer. Respekten for loven er utilstrækkelig forankret, og mekanismerne til at håndhæve den er ikke tilstrækkelig udviklede". Der var også kritik af serberne i Kosovo for at boykotte for eksempel Kosovos parlament på opfordring af Beograd.

Men der var da også lyspunkter i Kai Eides rapport - blandt andet udviklingen af demokratiske institutioner som det lokale parlament og den lokale regering, der havde fået flere og flere kompetencer overført. Dog noterer den norske diplomat, at den udvikling er blevet "undermineret af en stærk tendens blandt politikere til at se sig selv som ansvarlige over for de politiske partier frem for den offentlighed, som de tjener. Udnævnelser sker derfor ofte på baggrund af politisk og klanmæssig tilhørsforhold snarere end på kompetence."

Det er, som om Kai Eide ikke kan 
skrive et afsnit uden negative bemærkninger eller et afsnit uden positive iagttagelser for den sags skyld.

Det fører frem til konklusionen, som er et velkendt Kai Eide-synspunkt. Konklusionen lyder, at der ikke findes "et godt tidspunkt at tage fat på Kosovos fremtidige status. Det vil fortsætte med at være en meget følsom politisk sag. Ikke desto mindre fører en samlet bedømmelse til den konklusion, at tiden er inde til at begynde den proces (...). Ved at bevæge sig fra stagnation til forventning, kan stagnation ikke igen få lov til at vinde."

Det er svært at se, hvordan Kai Eide i efteråret i år skal nå frem til en anden konklusion end i sommeren 2004 kun et par måneder efter den voldsomme uro. Men hans konklusion svæver et godt stykke over hans analyse, og han kunne i virkeligheden have sparet sig arbejdet med at skrive rapporten. Hvis han ikke mener, at der nogensinde kommer et godt tidspunkt at indlede forhandlinger om Kosovos status, så er det vel lige meget, hvordan situationen ser ud på landjorden i Kosovo.

Med i det diplomatiske spil kom også, at Kai Eide forsinkede offentliggørelsen af sin rapport - efter sigende for at lægge pres på parterne i Kosovo for at leve op til standarderne. I sommer havde for eksempel EU's udenrigspolitiske koordinator, Javier Solana, besøgt Kosovo og klaget over, at implementeringen af standarderne var gået i stå. Han tal- te især om et forsøg på at skabe et par serbisk-dominerede kommuner, som i et fremtidigt Kosovo kan forsvare serbernes rettigheder.

Men før Kai Eide kunne offentliggøre sin rapport i begyndelsen af oktober, nåede Den Europæiske Union lige at give besked om, at Serbien nu havde gjort så mange fremskridt, at det kunne komme på tale at begynde at indlede forhandlinger om en stabiliserings- og associeringsaftale med EU - forløberen for et egentligt medlemskab. Det lignede en tanke at give Serbien en ordentlig luns kort før en rapport, der anbefaler forhandlinger, der sandsynligvis fører til, at Serbien mister Kosovo.

Herefter besluttede FN's Sikkerhedsråd i slutningen af oktober at indlede forhandlinger om Kosovos status, og FN's generalsekretær Kofi Annan udpegede den tidligere finske præsident Martti Ahtisaari som mægler. Ahtisaari, der også forhandlede med Slobodan Milosevic under bombekrigen i 1999, ventes at pendle frem og tilbage mellem Pristina og den serbiske hovedstad, Beograd, til at begynde med.

Men kan der ikke være noget om snakken, at det kunne skabe mere stabilitet med et selvstændigt Kosovo? Og at der er noget rigtigt i, at der ikke findes noget godt tidspunkt at drøfte Kosovos selvstændighed på. Jo, noget rigtigt er der i det, især hvis processen havde været noget mere ærlig. Og hvis ikke der var sto- 
re bekymringer for det serbiske mindretal. Mange serbere siger, at de vil rejse, hvis Kosovo bliver selvstændigt. Der er også frygt for, at albanernes løfter om at leve op til standarderne vil forsvinde i det øjeblik, de får deres eget land.

Men derudover er der også store bekymringer over det fremtidige Kosovo, som kan dukke op på den anden side af forhandlingerne.

\section{Blodhævn}

En af brudlinjerne i Europa går ved Kosovo. Brudlinjen skiller den slaviske verden - i form af for eksempel serbere og makedonere - fra den albanske. Og selv om vi kan synes, at vi har svært ved at forstå for eksempel serberne, så ligner vi dem mere, end vi ligner albanerne.

Det albanske samfund er præget af store familier eller klaner, som afgør mange forhold internt. Det er et lukket samfund med et traditionelt retssystem, der går tilbage til 1400tallet, da en adelsmand, Lek Dukagjin, samlede de uskrevne regler i en kanon. De udgøres af stærke æresbegreber, som skal håndhæves, og som kan føre til blandt andet blodhævn. I den anden ende af skalaen kan Lek Dukagjins kanon beskytte fremmede gæster, der overnatter i ens hus. Tidligere har man set eksempler på værter, der har ladet livet for at forsvare sine gæster.

At de traditionelle regler om blodhævn ikke er helt forsvundet, fik man et eksempel på så sent som i foråret, da Kosovos netop fratrådte regeringschef, Ramush Haradinajs, bror blev myrdet - uden tvivl som led i en blodfejde med en anden familie. Den fejde har allerede krævet adskillige dræbte i begge familier. Da Haradinajs bror blev dræbt, lød der opfordringer fra mere besindige kosovo-albanere om at standse blodfejden, som truer med at brede sig, og som i sidste ende, mente en analytiker, truer Kosovos muligheder for at blive selvstændig.

Det siger næsten sig selv, at det er svært at kombinere den form for traditionelt retsvæsen med et moderne retsvæsen. Og det er netop hvad det internationale samfund prøver på og det er måske her det går allerdårligst.

Chefanklageren fra krigsforbrydertribunalet for det tidligere Jugoslavien, Carla del Ponte, har sagt, at trusler mod vidner er almindeligt $i$ forbindelse med krigsforbrydersagerne i Haag, men det er særlig slemt med vidner fra Kosovo - de bliver truet i en sådan grad at kun omkring en håndfuld kosovo-albanere har vidnet åbent i Haag - altså ikke anonymt. Og her taler vi om vidner, der havde belastende oplysninger om anklagede albanere.

I andre tilfælde i Kosovos retssale er det ikke nødvendigt at true sig frem, fordi mange foretrækker at lade det traditionelle system tage sig af tvisterne, eller mange simpelthen er for bange til at vidne. 


\section{Organiseret kriminalitet}

Det siger næsten også sig selv, at i den situation stortrives organiseret kriminalitet og korruption. Og det er da også, hvad man hører fra mange både internationale i Kosovo og kritiske kosovo-albanere. Ja, især de internationale ser meget trætte ud, når man spørger om Lek Dukagjin og organiseret kriminalitet. Mafiaen ernærer sig blandt andet ved at smugle narkotika og ved at handle med kvinder.

Den organiserede kriminalitet menes også at have forbindelse til de albanske partier i Kosovo. Det siger for eksempel Dukagjin Gorani, den albanske chefredaktør for dagbladet Express. Avisen er kun et år gammel, men har allerede bragt mange afsløringer om organiseret kriminalitet og dens forbindelser til politikerne. Internationale embedsmænd i Kosovo, som arbejder med organiseret kriminalitet, bekræfter chefredaktør Goranis udtalelser om de tætte forbindelser mellem den organiserede kriminalitet og partiledere.

Dukagjin Gorani er en usædvanlig kosovo-albaner. I modsætning til de fleste albanere ser han meget dystert på Kosovos muligheder for at blive selvstændigt - og her især den form for samfund, som et selvstændigt Kosovo vil blive. Han siger ligeud, at han er bange for at blive smidt $\mathrm{i}$ fængsel, hvis de nuværende politiske ledere i Kosovo kommer til magten.
"Vi vil få et styre, der er negativt indstillet over for borgerne - en slags diktatur," siger han.

I foråret bragte hans avis og andre medier afsløringer af, at de politiske partier har deres egne efterretningstjenester, som ulovligt overvåger politiske modstandere og borgere. De menes også at være indblandet i organiseret kriminalitet. Partiernes efterretningstjenester menes at samarbejde med deres vestlige kolleger, siger Dukagjin Gorani.

Afløseren for den kosovo-albanske oprørsbevægelse, UCK, er Kosovos Demokratiske Parti. Det har ifølge chefredaktøren fortsat sit samarbejde fra krigens tid med USA, mens det andet store albanske parti, LDK, under ledelse af præsident Ibrahim Rugova skal være mere europæisk orienteret $\mathrm{og}$ have forbindelser til tysk og fransk efterretningsvæsen.

Præsident Rugova er i øvrigt syg af kræft, og der er frygt for, hvilken indflydelse det kan få på forhandlingerne om Kosovos status. De albanske partier har prøvet at finde et fælles udgangspunkt før forhandlingerne, men de er dybt splittede.

Samtidig er der dukket en mystisk militant albansk selvstændighedsbevægelse op i det vestlige Kosovo. Bevægelsen, der kalder sig Hæren for Kosovos Selvstændighed, opretter vejspærringer om natten, så FN's styre har rådet sine ansatte til ikke at bevæge sig om natten i området.

Formålet med gruppen er klart at lægge pres på det internationale 
samfund for at give Kosovo selvstændighed. Sammen med en række episoder i de seneste måneder blandt andet drabet på to unge serbere - kan beskeden være: Hvis I holder fast i Kosovo, bliver det værst for jer selv, vi vil gøre det så besværligt som muligt for jer.

\section{Selvstændighed light}

Ligesom meget tyder på, at rapporten om Kosovos standarder var skrevet på forhånd, så er Kosovos status også fastlagt. Det bliver en form for selvstændighed - en betinget uafhængighed - en model protektorat light, kunne man kalde den.

Kosovo vil blive selvstændigt, men stadig med en international styrke til stede, om end knap så stor som $\mathrm{i}$ dag. Der vil også være en mindre politistyrke og måske også internationale dommere og en EU-repræsentant med en vis magt. Det foreslår flere tænketanke, og diplomater siger da også, at de er sikre på, at betinget selvstændighed bliver løsningen. Og det internationale samfund er nok også villig til at acceptere en vis etnisk udrensning af serbere som følge af selvstændigheden. Imens fortsætter hele den her tvivlsomme proces, fordi den internationale opmærksomhed er rettet andre steder hen i verden.

Søren Jessen-Petersen advarede i august 2004, da han tiltrådte, mod at forhandlinger om en status for Kosovo, blev set som en belønning for volden nogle måneder før. Men det er svært at få en anden opfattelse, når processen blev sat i gang umiddelbart efter uroen.

Hvis der er tale om en belønning, falder den godt i tråd med det internationale samfunds adfærd $i$ andre situationer i de seneste år på Balkan. Albanerne i Makedonien blev, hvad enten man mener deres krav var rimelige eller ej, belønnet for et voldeligt oprør i 2001. Serberne i Bosnien \& Hercegovina blev også belønnet med Dayton-aftalen i 1995 for deres etniske udrensning, og kroaterne fordrev samme år tusinder af serbere med en stiltiende accept fra blandt andet USA.

Thomas Hjortsø er journalist ved Orientering, DR P1, med Balkan som speciale 